\title{
PENGARUH KARAKERISTIK PERUSAHAAN DAN STRUKTUR KEPEMILIKAN TERHADAP PENGHINDARAN PAJAK / TAX A VOIDANCE PADA PERUSAHAAN BUMN YANG TERDAFTAR PADA BEI TAHUN 2013-2016
}

\author{
Arviyanti \\ STIE Muhammadiyah Jakarta \\ Enong Muiz \\ STIE Muhammadiyah Jakarta
}

\begin{abstract}
Abstrak
Penelitian ini dilakukan untuk mengetahui bukti empiris pengaruh karakteristik perusahaan dan struktur kepemilikan terhadap penghindaran pajak / tax avoidance pada perusahaan Badan Usaha Milik Negara (BUMN) yang terdaftar pada Bursa Efek Indonesia (BEI) tahun 2013 2016. Sampel yang digunakan sebanyak 15 perusahaan selama 4 tahun sehingga jumlah sampel sebanyak 60 data perusahaan. Analisis data yang digunakan adalah GLS (General Least Square) dengan bantuan Eviews versi 9. Untuk variabel independen, variabel karakteristik perusahaan diproksikan pada profitabilitas (Return On Asset/ROA), leverage (Debt to Equity Ratio/DER), ukuran perusahaan (Size), intensitas modal (Capital Intensity Ratio/ CIR). Variabel struktur kepemilikan diproksikan pada kepemilikan manajerial (OWNMANAG) dan kepemilikan institusional (OWNINS). Sedangkan untuk variabel dependen penghindaran pajak diproksikan pada tariff pajak efektif (ETR/ Effective Tax Rate). Hasil dari penelitian ini adalah Pengaruh kareakteristik perusahaan yang di proksikan pada ROA, DER, Size, CIR hanya ROA yang berpengaruh negative signifikan terhadap penghindaran pajak. DER dan Size berpengaruh negative tidak signifikan Sedangkan dan CIR berpengaruh positif tetapi tidak signifikan terhadap penghindaran pajak. Pengaruh Struktur Kepemilikan yang diproksikan pada kepemilikan manajerial berpengaruh positif tidak signifikan terhadap penghindaran pajak dan kepemilikan institusional berpengaruh negative tidak signifikan terhadap penghindaran pajak.

Kata kunci: Penghindaran pajak (ETR), Profitabilitas (ROA), Leverage (DER), Ukuran perusahaan (Size), Intensitas modal (Capital Intensity Ratio/ CIR), Kepemilikan manajerial, Kepemilikan institusional.
\end{abstract}

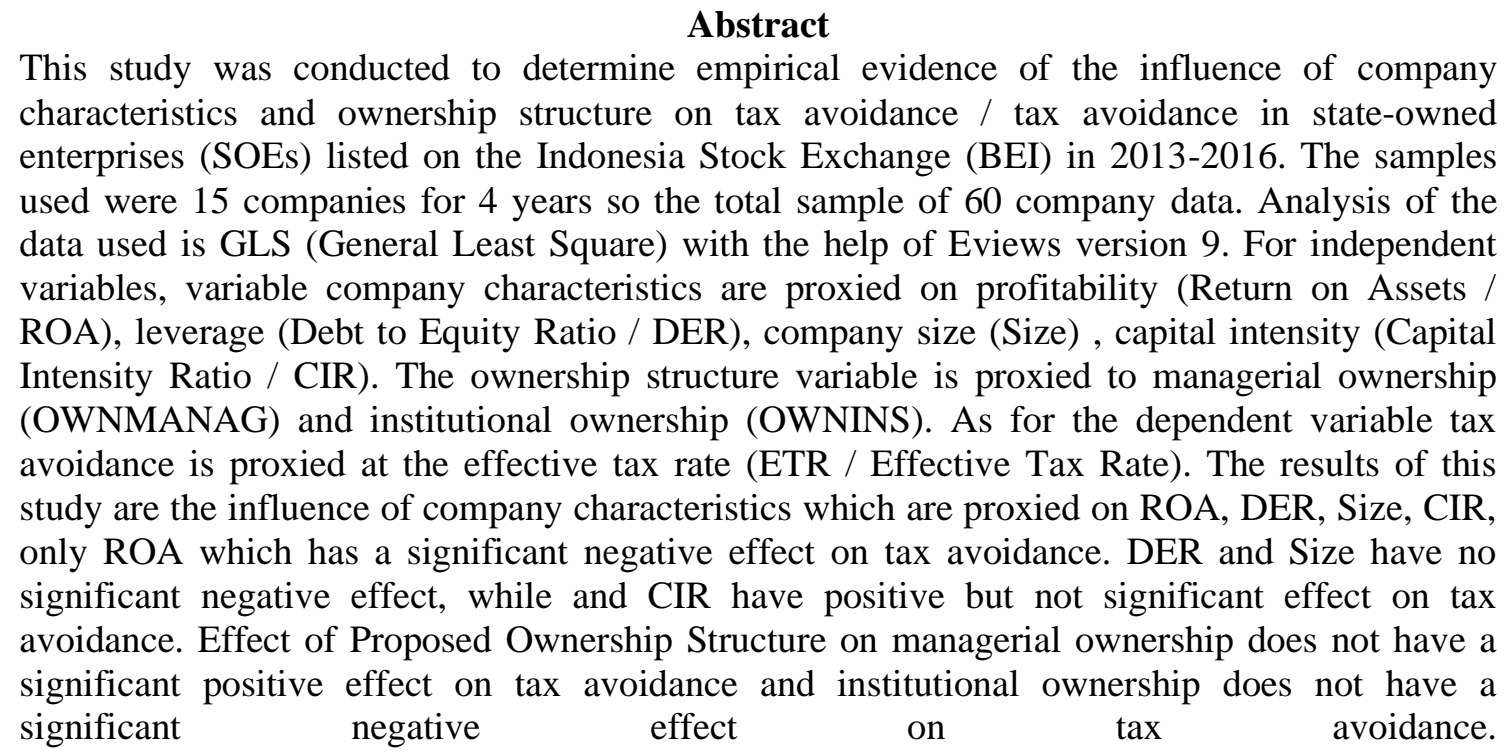
Keywords: Tax avoidance (ETR), profitability (ROA), leverage (DER), company size (size), capital intensity (CIR), managerial ownership, institutional ownership. 


\section{PENDAHULUAN}

Sumber pendapatan Negara paling besar di peroleh dari penerimaan pajak yang dilakukan oleh para wajib pajak orang pribadi maupun badan karena pajak bersifat memaksa dan di wajibkan. Hasil Badan Pusat Statistik mengenai Realisasi Penerimaan Negara tahun 2013- 2016 dari pajak seamakin meningkat. Dari tahun 2013 sebesar1.077.307, 2014 sebesar 1.146.866, 2015 sebesar 1.240.419, sampai 2016 penerimaan berasal dari pajak sebesar1.284.970 (milyaran rupiah).

Penerimaan pajak tersebut akan tetapi tidak sesuai dengan target yang di harapkan pemerintah dikarenakan masih banyaknya tindakan penghindaran pajak yang dilakukan oleh wajib pajak.

Pada dasarnya pembayaran pajak merupakan perwujudan dari kewajiban warga Negara dan peran serta wajib pajak untuk secara langsung dengan bersama - sama melaksanakan kewajiban perpajakan untuk pembiayaan Negara dan pembangunan nasional seperti yang tercantum pada Undang - Undang Dasar 1945 pasal 23 ayat 2 yang berbunyi "Segala pajak untuk keperluan Negara berdasarkan undang undang" yang telah mengalami perubahan atau amandemen terdapat pada pasal 23A yang berbunyi "Pajak dan pungutan lain yang bersifat memaksa untuk keperluan Negara diatur dengan undang - undang".

Segala macam upaya telah dilakukan pemerintahan untuk meningkatkan penerimaan pajak. Pada tahun 2010 pemerintahan Indonesia telah memberikan berbagai insentif di bidang perpajakan, antara lain:

Penurunan tarif PPh badan dari $28 \%$ menjadi $25 \%$ sebagaimana diamanatkan dalam UU No 36 tahun 2008 pasal 17 ayat 1b\&2a Pemberian keringanan tariff PPh badan $5 \%$ lebih rendah dari tarif normal bagi perusahaan yang minimal $40 \%$ sahamnya dimiliki oleh publik dalam UU No 36 tahun 2008 pasal 17 ayat 2b Pelaksanaan amandemen undang-undang PPN (UU no 42 tahun 2009) yang secara umum lebih memberikan kepastian hukum bagi wajib pajak dan meningkatkan daya saing bagi pengusaha Indonesia di luar daerah pabean Pemberian insentif berupa pajak ditanggung pemerintah (DTP) atas PPh, PPN dan bea masuk guna mendorong investasi dan kegiatan dunia usaha serta stabilisasi harga di dalam negeri (Kementerian Keuangan RI,2012)

Berdasarkan penelitian Wicaksono (2015) fakta yang terjadi di masyarakat adalah belum semua WP taat memenuhi kewajibannya, sehingga penerimaan Negara dari sumber pajak di nilai masih rendah. Tahun 2016, pemerintah Indonesia mengeluarkan Undang Undang (UU) no 11 tentang pengampuan pajak atau tax amnesty. Pemerintah menilai bahwa banyak harta warga Negara Indonesia yang di tempatkan di luar wilayah Negara Kesatuan Republik Indonesia, baik dalam bentuk likuid maupun non likuid. Kenyataannya tidak semua harta tersebut telah dilaporkan di dalam SPT tahunan oleh pemiliknya, bahkan mungkin banyak yang belum terungkap karena wajib pajak menghindari kewajiban membayar pajak. Penerbitan UU Nomor 11 Tahun 20116 tax amnesty penghapusan pajak menunjukkan telah terjadinya tindakan penghindaran pajak dengan memanfaatkan tax heaven / perlindungan pajak. Pajak diasumsikan sebagai biaya karena mengurangi laba. Perusahaan yang sudah go public umumnya cenderung hight profile dari pada perusahaan yang belum gopublic. Agar harga sahamnya meningkat, manajer go public akan berusaha tampil sebaik mungkin, sukses dan membagi deviden yang besar. Demikian juga dengan pembayaran pajaknya akan diusahakan sebaik mungkin (Suandy,2014:5).

Salah satu cara yang digunakan adalah penghindaran pajak. Penghindaran pajak menunjuk kepada rekayasa tax affairs yang masih tetap dalam bingkai ketentuan perpajakan (Suandy,2014:7).

Berkaitan dengan pengindaran pajak diatas, secara umum terdapat dua jenis perlawanan yang sering di lakukan oleh wajib pajak atau masyarakat yang dapat menghambat dalam upaya pemungutan pajak (Mardiasmo, 2011). Jenis perlawanan yang pertama adalah perlawanan pasif, yaitu perlawanan yang disebabkan oleh beberapa hal, antara lain karena perkembangan intelektual dan moral masyarakat, rumitnya sistem perpajakan untuk dipahami dan dijalankan, kurangnya sistem kontrol dan pelaksanan pemungutan pajak. Jenis perlawanan yang kedua adalah perlawanan aktif yaitu semua usaha yang dilakukan oleh wajib pajak untuk 
menghindari pajak, baik yang bersifat Legal (tax avoidance) maupun yang bersifat ilegal/melanggar undang-undang (tax evasion). Apapun bentuk perlawanan yang dilakukan oleh wajib pajak tentu saja akan berimbas pada terhambatnya upaya pemungutanpajak yang akhirnya berujung pada tidak maksimalnya jumlah pajak yang bisa dikumpulkan.

Mengutip dari berita "Kontan.co.id (Rabu,16/09/2015) JAKARTA. Kewajiban formal wajib pajak Indonesia tergolong rendah. Dari tahun ke tahun, Direktorat Jenderal (Ditjen) Pajak Kementerian Keuangan belum juga berhasil membenahi kepatuhan wajib pajak melaporkan pajaknya. Data Ditjen Pajak menunjukan, tingkat kepatuhan wajib pajak orang pribadi per 10 September 2015, baru 56,36\%. Angka tersebut diperoleh dari jumlah pelaporan Surat Pemberitahuan (SPT) wajib pajak orang pribadi dibandingkan dengan jumlah orang pribadi yang memiliki Nomor Pokok Wajib Pajak (NPWP). Angka itu jauh lebih rendah ketimbang tingkat kepatuhan 2014 yang mencapai 59,88\%. Direktur Penyuluhan, Pelayanan, dan Hubungan Masyarakat (P2Humas) Ditjen Pajak Mekar Satria Utama berkilah, data tersebut tidak bisa dibandingkan. Sebab, "Data tahun 2014 itu sudah sampai dengan Desember 2014. Sedangkan untuk tahun 2015 itu baru per 10 September," ujarnya, Selasa (15/9).

Tidak hanya itu, tingkat kepatuhan wajib pajak badan per 10 September 2015 baru sebanyak 49,74\%. Walaupun masih tergolong minim, capaian ini lebih tinggi dari tahun 2014, sebesar 47,34\%. Kenaikan, klaim Ditjen Pajak, disebabkan banyak wajib pajak badan yang mulai memanfaatkan fasilitas penghapusan sanksi administrasi sebagaimana diatur dalam Peraturan Menteri Keuangan (PMK) Nomor 91/PMK.03/2015.

Dan dari "CNN Indonesia (Jumat, 06/05/2016) Jakarta, CNN Indonesia -- Direktorat Jenderal Pajak (DJP) mencatat jumlah wajib pajak yang melaporkan Surat Pemberitahuan (SPT) tahun pajak penghasioan (PPh) hingga 30 April 2016 sebanyak 11,67 juta. Angka itu meningkat 13 persen dibandingkan dengan realisasi SPT periode yang sama tahun lalu 10,32 juta wajib pajak (WP). Namun jika dibandingkan dengan target 14,6 juta SPT yang ditetapkan DJP, realisasi pelaporan SPT pada tahun ini hanya 83,3 persen atau kurang 2,93 juta SPT. Dari 11,67 juta SPT yang terkumpul, wajib pajak orang pribadi (WPOP) menjadi pelapor SPT terbanyak yakni 11,12 juta atau 95,28 persen. Tingkat kepatuhan WPOP meningkat 13,77 persen jika dibandingkan dengan realisasi pelaporan SPT tahn lalu 9,77 juta SPT. Statistik DJP menunjukkan, mayoritas WPOP melaporkan SPT secara elektronik melalui aplikasi e-filling. Tercatat jumlah SPT WPOP yang masuk melalui aplikasi e-filling sebanyak 7,69 juta atau 69 persen dari total SPT WPOP. Sedangkan sekitar 30,5 persen atau 3,39 juta SPT dilaporkan secara manual, dan sisanya sebanyak 38.121 SPT masuk melalui e-SPT. Sementara tingkat kepatuhan WP badan sejauh ini belum menunjukkan perbaikan yang signifikan. Tercatat jumlah SPT yang dilaporkan WP badan hingga berakhirnya masa pelaporan SPT, 30 April 2016, hanya meningkat 1 persen, yakni dari 543.092 SPT pada 30 April 2015 menjadi 549.059 SPT. Angka itu menyumbang hanya 4,7 persen dari total SPT yang terkumpul. Sesuai ketentuan, batas akhir pelaporan SPT untuk WP orang pribadi adalah 31 Maret setiap tahunnya, sedangkan untuk WP badan paling lambat 30 April. Namun karena permasalahan teknis sistem pelaporan online, untuk tahun ini DJP memperpanjang sebulan masa pelaporan SPT untuk WP orang pribadi menjadi sama dengan WP badan hingga 30 April 2016. Sebelumnya, Direktur Pelayanan dan Penyuluhan Hubungan Masyarakat (P2 Humas) DJP Mekar Satria Utama mengatakan target pelaporan SPT pada tahun ini sebanyal 14,6 juta SPT. Khusus untuk target pelaporan SPT via efilling ditetapkan sebanyak 7 juta WP.

Beberapa penelitian sebelumnya mencoba mengkaitkan karakteristik perusahaan berdasarkan faktor kondisi keuangan perusahaan terhadap tax avoidance, diantaranya memfokuskan pada tingkat profitabilitas perusahaan (ROA), leverage, ukuran perusahaan (size), capital intensity ratio.

Dalam penelitian Rosalia (2017) menyatakan profitabilitas (ROA) tidak berpengaruh terhadap penghindaran pajak. Mahaputra (2016) menyatakan bahwa laba atas asset sebagai proxy dari profitabilitas berpengaruh positif terhadap penghindaran pajak. Menurut Siregar (2016) menyatakan bahwa leverage berpengaruh signifikan terhadap penghindaran pajak, size berpengaruh signifikan, dan variable profitabilitas, capital intensity, inventory intensity tidak 
berpengaruh signifikan terhadap praktik penghindaran pajak. Beberapa penelitian sebelumnya juga mencoba mengkaitkan struktur kepemilikan terhadap tax avoidance, diantaranya memfokuskan pada kepemilikan manajerial dan kepemilikan institusional. Menurut Utami (2013) menyatakan bahwa kepemilikan manajerial dan kepemilikan institusional tidak berpengaruh terhadap tax avoidance. Tendean menyatakan bahwa kepemilikan institusional dapat memoderasi faktor terjadinya tax avoidance. Penghindaran pajak yang marak muncul di media masa terjadi antara lain pada perusahaan BUMN yang menurut masyarakat perusahaan BUMN/BUMD yang diduga tidak mungkin melakukan penghindaran pajak karena sudah diberi kepercayaan oleh Negara sebagai wajib pajak beresiko rendah berdasarkan PER 31/PJ/2010 serta SE 45/PJ/2012 yang menjelaskan atas pelaksanaan Peraturan Menteri Keuangan Nomor 136/PMK.03/2012 A umum sebagai fungsi BUMN/ BUMD yang ditunjuk sebagai pemungut / pemotong pajak.

Telaah penulisan ini ditujukan untuk melihat secara teoritis pelaksanaan Karakteristik perusahaan, Struktur Kepemilikan dalam upaya untuk mengetahui keterkaitan dengan pengindaran pajak yang memfokuskan pada tingkat profitabilitas perusahaan (ROA), leverage, ukuran perusahaan (size), capital intensity ratio.

\section{KAJIAN LITERATUR}

Iuran kepada negara (yang dapat dipaksakan) yang terutang oleh yang wajib membayarnya menurut peraturan-peraturan, dengan tidak mendapat prestasi kembali, yang langsung dapat ditunjuk, dan yang gunanya adalah untuk membiayai pengeluaran-pengeluaran umum berhubungan dengan tugas negara untuk menyelenggarakan pemerintahan.Pajak adalah iuran rakyat kepada kas negara berdasarkan undangundang(yang dapat dipaksakan) dengan tidak mendapat jasa timbal (kontraprestasi), yang langsung dapat ditunjukkan dan yang digunakan untuk membayar pengeluaran umum. Pajak pada dasarnya adalah setoran rakyat kepada kas negara yang pada akhirnya juga akan dipergunakan untuk kepentingan dan kesejahteraan rakyat sendiri. Pajak adalah iuran rakyat kepada kas negara yang dapat dipaksakan berdasarkan undang-undang tanpa adanya kontraprestasi yang langsung dapat ditunjukkan dan dipergunakan untuk membiayai keperluan negara (Mardiasmo, 2011).

Menurut Rochmat Soemitro dalam bukunya yang berjudul Pengantar Hukum pajak (1992) diungkapkan bahwa "Pajak adalah peralihan kekayaan dari sektor swasta ke sektor publik berdasarkan undang - undang yang dapat dipaksakan dengan tidak mendapatkan imbalan (tegenprestatie) yang secara langsung dapat ditunjukkan, yang digunakan untuk membiayai pengeluaran umum dan sebagai alat pendorong, penghambat atau pencegah, untuk mencapai tujuan yang ada diluar bidang keuangan Negara. Menurut Undang - Undang Republik Indonesia No 28 tahun 2007 dan No 16 Tahun 2009 tentang KUP pasal 1 di jelaskan bahwa, "pajak adalah konstribusi wajib kepada negara yang terutang oleh orang pribadi atau badan yang bersifat memaksa berdasarkan Undang - Undang, dengan tidak mendapat imbalan secara langsung dan digunakan untuk keperluan Negara bagi sebesar - besarnya kemakmuran rakyat".

Teori agensi adalah teori yang menyatakan adanya hubungan antara pihak yang memberi wewenang (principal) dan pihak yang menerima wewenang (agen) (Ardiansah,2014). Teori agensi muncul ketika adanya hubungan kerja antara satu orang atau lebih (principal) memberi wewenang dan bekerja sama dengan orang lain (agen) untuk menerima wewenang dan menjalankan perusahaannya (Jensen \& Meckling (1976) dalam Astuti (2016). Dari penjelasan diatas dapat disimpulkan bahwa teori agency adalah teori yang muncul karena adanya kerjasama dimana ada pemberi wewenang dan penerima wewenang untuk mencapai tujuan bersama. Manajer berkewajiban untuk mengelola perusahan dengan sebaik - baiknya sehingga perusahaan akan mendapatkan laba yang cukup signifikan. Bagi perusahaan, pajak merupakan beban yang akan mengurangi laba bersih. Disinilah mulai terjadi agency problem atau perbedaan kepentingan yang akan mendorong terjadinya penghindaran pajak. Masdupi (2005) dalam Mahadewi (2017) mengemukakan cara - cara untuk mengatasi masalah keagenan antara lain: (1) meningkatkan kepemilikan manajerial, (2) pendekatan pengawasan eksternal dan (3) 
institutional investor sebagai monitoring agent. Untuk mengatasi atau meminimalisasi masalah agensi tersebut maka dilakukan 2 cara berikut ini (Arfan, 2016):

\section{Market Force}

Market force merupakan pemegang saham yang memiliki saham mayoritas. Melalui hak suara mayoritas maka diyakini akan dapat mengatasi masalah agensi. Hal tersebut dilakukan dengan cara memberi tekanan kepada manager untuk bekerja dengan baik maupun mengganti manajemen yang dianggap tidak dapat memenuhi kesejahteraan pemegang saham atau pemilik perusahaan.

\section{Agency Cost}

Agency cost biaya yang akan dikeluarkan untuk mengurangi agency problem sekaligus untuk pemenuhan kesejahteraan para pemegang saham. Biaya yang dikeluarkan antara lain, berasal dari biaya insentif yang akan diberikan kepada manajer untuk memaksimalkan harga saham.

Kirchler, Maciejovsky, dan Schneider (2002) berpendapat penghindaran pajak mengacu pada pengurangan pembayaran pajak dengan cara yang legal, misalnya melalui celah celah peraturan perpajakan yang ada. Penghindaran pajak (tax avoidance) adalah upaya pengurangan secara legal yang dilakukan dengan cara memanfaatkan ketentuan ketentuan di bidang perpajakan secara optimal seperti, pengecualian dan pemotongan - pemotongan yang di perkenankan maupun manfaat hal - hal yang belum diatur dan kelemahan kelemahan yang ada dalam peraturan perpajakan yang berlaku (Suandy, 2005 dalam Lestari 2015). Dari pengertian pengertian diatas dapat disimpulkan bahwa penghindaran pajak adalah upaya pengurangan / meminimalisir bahkan menghindari adanya pembayaran pajak tanpa melanggar hukum.

Dalam penelitian ini cara pengukuran penghindaran pajak menggunakan proksi ETR (Effective Tax Rate). ETR yang rendah menjadi indikator penghindaran pajak karena dengan mengurangi penghasilan kena pajak perusahaan dan dengan tetap menjaga laba akuntansi keuangan yang menjadikan ETR rendah. ETR dapat di rumuskan sebagai berikut (Jane Atari, 2016):

ETR (it) $=($ Beban Pajak it $) /($ Laba Sebelum Pajak it)

Setiap perusahaan mempunyai ciri khas perusahaannya masing masing, perusahaan besar cenderung akan melakukan perencanaan pajak untuk melakukan penghndaran pajak (Surbakti,2012).

Setiap perusahaan mempunyai ciri khas perusahaannya masing masing, perusahaan besar cenderung akan melakukan perencanaan pajak untuk melakukan penghndaran pajak (Surbakti,2012). Karakteristik perusahaan juga dapat mempengaruhi variasi tarif pajak efektif antar perusahaan, seperti perusahaan yang melakukan pembiayaan lewat hutang akan menghasilkan pajak yang kecil (Brigham \& Houston, 2011 dalam Hijriani,2014).

Karakteristik perusahaan yang di gunakan dalam penelitian ini antara lain:

\section{Profitabilitas Perusahaan (ROA)}

Salah satu faktor yang mempengaruhi kemampuan perusahaan untuk memberikan imbalan kepada para pemiliknya adalah profitabilitas (Hartanto, 249,2013). Rasio profitabilitas merupakan rasio untuk menilai kemampuan perusahaan dalam mencari keuntungan atau laba dalam suatu periode tertentu. Rasio ini juga memberikan ukuran tingkat efektivitas manajemen suatu perusahaan yang ditunjukkan oleh laba yang dihasilkan baik dari penjualan atau dari pendapatan investasi. Dikatakan perusahaan rentabilitasnya baik apabila mampu memenuhi target laba yang telah di tetapkan dengan menggunakan aktiva atau modal yang dimilikinya (Kasmir,2016:114). Return On asset (ROA) merupakan salah satu ratio yang dapat mengukur profitabilitas perusahaan. ROA yang diukur melalui rasio dari laba sebelum pajak terhadap total 
asset akan mengontrol dampak dari perubahan laba akuntansi (Gupta dan Newberry (1997) dalam Surbakti (2012).

Dari pengertian diatas dapat kita simpulkan bahwa ROA adalah rasio yang digunakan untuk menilai kemampuan perusahaan dalam menghasilkan laba melalui total asset yang dimiliki perusahaan tersebut.

\section{Leverage}

Leverage adalah salah satu rasio keuangan yang menggambarkan hubungan antara hutang perusahaan terhadap modal maupun asset perusahaan (kuriah,2016). Husnan (2012) yang menyatakan bahwa rasio leverage adalah rasio yang mengukur seberapa jauh perusahaan menggunakan hutangnya.

Dari uraian diatas mengenai leverage dapat kita simpulkan bahwa leverage adalah rasio yang digunakan untuk menilai seberapa besar operasi perusahaan dibiayai dengan hutang.

\section{Ukuran Perusahaan (size)}

Ukuran perusahaan adalah suatu skala dimana dapat diklasifikasikan besar kecil perusahaan menurut berbagai cara, antara lain: total aktiva, log size, penjualan dan kapitalisasi pasar, dan lain - lain (Hasibuan (2009) dalam Surbakti (2012)). Ukuran perusahaan menunjukkan besar kecilnya perusahaan. Sebuah perusahaan yang ukuran / skalanya besar dan sahamnya tersebar luas memiliki kekuatan tersendiri dalam menghadapi bisnis dan kemampuan perusahaan untuk menghasilkan laba lebih tinggi karena usaha tersebut di dukung oleh asset yang besar. Hal tersebut menggambarkan bahwa perusahaan besar memiliki jumlah laba sebelum pajak yang besar dan memiliki insentif serta sumber daya yang lebih besar untuk melakukan manajemen pajak (Fitri anita, 2015). Ukuran perusahaan menunjukkan besar kecilnya perusahaan. Sebuah perusahaan yang ukuran / skalanya besar dan sahamnya tersebar luas memiliki kekuatan tersendiri dalam menghadapi bisnis dan kemampuan perusahaan untuk menghasilkan laba lebih tinggi karena usaha tersebut di dukung oleh asset yang besar. Hal tersebut menggambarkan bahwa perusahaan besar memiliki jumlah laba sebelum pajak yang besar dan memiliki insentif serta sumber daya yang lebih besar untuk melakukan manajemen pajak (Fitri anita, 2015).

\section{Capital Intensity Ratio}

Intensitas modal mencerminkan seberapa besar modal yang dibutuhkan perusahaan untuk menghasilkan pendapatan. Stickney dan MC Gee (1982) dalam Surbakti (2012) menjelaskan bahwa Capital intensity dapat dijelaskan sebagai rasio dari net property, plant and equipment terhadap total asset (dalam nilai buku). Perusahaan yang memutuskan untuk berinvestasi dalam bentuk aset tetap dapat menjadikan biaya penyusutan sebagai biaya yang dapat dikurangkan dari penghasilan atau bersifat deductible expense.

Variabel bebas terakhir yang di teliti dalam penelitian ini adalah Struktur kepemilikan. Struktur kepemilikan merupakan berbagai macam pola dan bentuk dari kepemilikan suatu perusahaan atau prosentase kepemilikan saham yang dimiliki oleh pemegang saham internal dan pemegang saham eksternal (Sanjaya,2017). Pendapat lain menurut Mei Yuniati, Kharis Raharjo, Abrar Oemar (2016) menyatakan bahwa struktur kepemilikan saham adalah proposi kepemilikan manajemen, institusional dan kepemilikan publik dan struktur kepemilikan merupakan mekanisme untuk mengurangi konflik antara manajemen dengan pemegang saham. Komposisi pemegang saham terdiri dari kepemilikan pihak dalam (insider) dan kepemilikan pihak luar (outsider). Outsider dapat berupa institusi domestic, institusi asing, pemerintah, individu domestic maupun asing.Insider sering disebut dengan managerial ownership atau kepemilikan manajerial.

Dalam penelitian ini struktur kepemilikan hanya mencakup kepemilikan manajerial dan kepemilikan institusional di karenakan dalam perusahaan BUMN di dominasi oleh kepemilikan pemerintah sehingga struktur kepemilikan yang memungkinkan melakukan atau tidak 
melakukan penghindaran pajak adalah struktur kepemilikan manajerial dan kepemilikan institusional.

\section{Kepemilikan Manajerial}

Pemegang saham internal adalah orang yang memiliki saham dan termasuk di dalam struktur organisasi perusahaan, yang artinya orang tersebut juga melaksanakan fungsinya sebagai pelaksana operasi (manajer atau direksi) atau sebagai pengawas kegiatan operasi perusahaan (dewan komisaris) (Sanjaya,2017).

Sonya Majid (2016:4) menyatakan bahwa kepemilikan manajerial adalah pemegang saham dari pihak manajemen yang secara aktif ikut dalam pengambilan keputusan di dalam perusahaan, misalnya direktur dan komisaris.

Kepemilikan Manajerial dihitung dengan rumus sebagai berikut Gideon (2005) dalam Mahadewi (2017):

Kep.Manajerial $(\mathrm{KM})=($ Jumlah saham yang dimiliki direksi@ komisaris dan manajer $) /$ (jumlah saham yang beredar) x $100 \%$

\section{Kepemilikan Istitusional}

Kepemilikan institusional adalah kepemilikan perusahaan atas institusi oleh pihak luar perusahaan. Dalam hal ini yang dimaksud adalah institusi seperti perusahaan asuransi, bank, perusahaan investasi dan kepemilikan oleh institusi - institusi lain yang menjadi peningkatan pengawasan atas perusahaan tersebut. Kepemilikan institusional memiliki kelebihan antara lain (Sanjaya,2017):

Memiliki profesionalisme dalam menganalisis informasi sehingga dapat menguji keandalaninformasi.

Memilik motivasi yang kuat untuk melaksanakan pengawasan lebih ketat atas aktivitas yang terjadi dalam perusahaan

Kepemilikan institusional adalah tingkat kepemilikan saham institusional dalam perusahaan, diukur oleh proporsi saham yang dimiliki institusional pada akhir tahun yang dinyatakan dalam prosentase (Beiner et al (2003) dalam Mahadewi (2017)) dihitung dengan rumus sebagai berikut:

Kep. institusional $(\mathrm{KI})=$ Jumlah saham yang dimiliki institusi/jumlah saham yang beredar $\mathrm{x} 100 \%$

Berdasarkan permasalahan yang menjadi latar belakang penelitian ini, yaitu mengenai pengaruh karakteristik perusahaan dan struktur kepemilikan terhadap penghindaran pajak serta berdasarkan kajian teoritis maupun penelitian-penelitian terdahulu maka dapat dibuat kerangka pemikiran seperti pada gambar dibawah ini.

$$
\text { H3 } \begin{gathered}
\text { H1 } \\
\text { simultan } \\
\text { H2 }
\end{gathered}
$$

Gambar 1 Kerangka Pemikiran

Sumber: Data Peneliti,2018

Gambar tersebut menunjukan bahwa pada penelitian ini, semua variabel penelitian yaitu karakteristik perusahaan dan struktur kepemilikan diduga menjadi penyebab pengaruh secara positif terhadap variabel pengindaran pajak.

Hipotesis dalam penelitian ini adalah sebagai berikut:

Terdapat Pengaruh Signifikan Profitabilitas terhadap penghindaran pajak

Terdapat Pengaruh Signifikan Leverage terhadap penghindaran pajak

Terdapat Pengaruh Signifikan size terhadap penghindaran pajak 
Terdapat Pengaruh Signifikan capital intensity ratio terhadap penghindaran pajak Terdapat Pengaruh Signifikan kepemilikan manajerial terhadap penghindaran pajak Terdapat Pengaruh negative signifikan kepemilikan institusional terhadap penghindaran pajak. Terdapat Pengaruh signifikan Profitabilitas, Leverage, size, capital intensity ratio dan kepemilikan manajerial secara bersama-sama (simultan) terhadap penghindaran pajak.

\section{METODE}

Penelitian yang dilakukan adalah penelitian kuantitatif dimana jenis data yang digunakan adalah data sekunder yaitu data penelitian yang diperoleh secara tidak langsung melalui media perantara (diperoleh dan dicatat oleh orang lain). Sumber data untuk penelitian ini diperoleh dari situs Bursa Efek Indonesia melalui website www.idx.co.id. Metode penentuan sampel yang digunakan adalah teknik purposive sampling yaitu teknik yang digunakan dalam penentuan sampel yang dipilih berdasarkan kriteria tertentu dan berdasarkan pertimbangan tertentu yang disesuaikan dengan tujuan penelitian. Yaitu sebagai berikut:

- Seluruh perusahaan BUMN yang terdaftar pada Bursa Efek Indonesia (BEI) periode tahun 2013 - 2016 dan bukan merupakan perusahaan listing maupun delisting pada tahun penelitian.

- Perusahaan BUMN yang menerbitkan Laporan Tahunan secara rutin dari tahun 2013 $-2016$.

- Perusahaan BUMN dengan pajak penghasilan positif antara tahun 2013 - 2016.

- Perusahaan BUMN yang memiliki kelengkapan data keuangan untuk tahun 2013 sampai dengan 2016 yang diperlukan untuk pengukuran keseluruhan variabel.

- Perusahaan BUMN yang menggunakan mata uang rupiah. Kriteria ini diperlukan agar pengukuran nilai mata uangnya sama.

Metode analisis data yang digunakan dalam penelitian ini adalah analisis data panel, sehingga data yang dimiliki tidak hanya berdasarkan satu periode saja tetapi mencakup beberapa periode. Untuk mengestimasi parameter model dengan data panel, terdapat beberapa teknik yang digunakan yaitu: Pooled Least Square (Common Effect), Fixed Effect Model, Random Effect Model. Alat analisi yang digunakan adalah regresi data panel dengan 3 pendekatan yaitu Uji F Restricted (Chow Test), Uji Hausman, Uji Lagrange Multiplier (LM).

\section{HASIL DAN PEMBAHASAN HASIL}

Pada tabel xx dibawah ini disajikan deskripsi variabel - variabel penelitian yaitu ETR, ROA, DER, size, capital intensity, kepemilikan managemen dan kepemilikan institusi. Jumlah perusahaan BUMN yang terdaftar pada BEI sebanyak 15 sampel perusahaan dengan tahun pengamatan dari tahun 2013 - 2016 sehingga total sampel pengamatan sebanyak 60 data panel.

Tabel 1 Deskripsi Variabel Penelitian

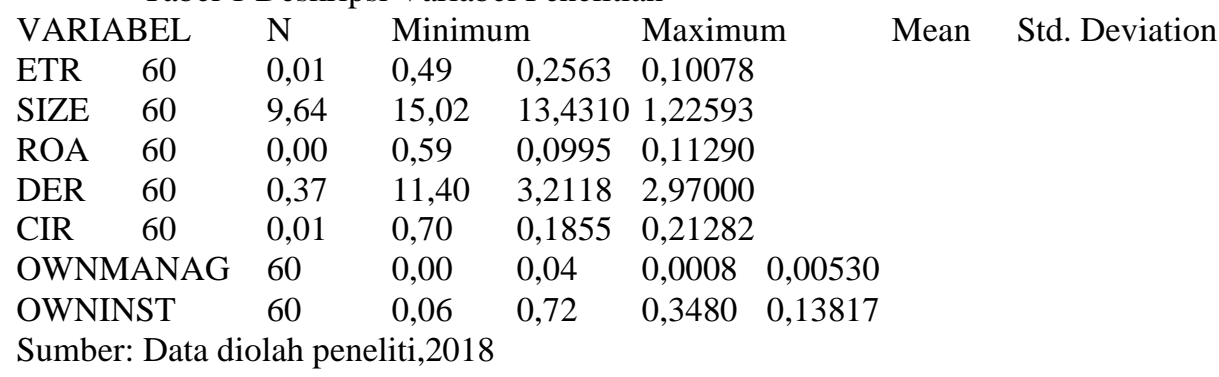

Berdasarkan data diatas, terlihat bahwa nilai minimum ETR (Effective Tax Rate) sebesar 0,01 dan maksimum sebesar 0,49. Sementara nilai standar deviasi ETR sebesar 0,10078 dengan nilai rata rata ETR yang dimiliki perusahaan BUMN periode 2013 -2016 adalah 0,2563. Nilai 
terendah dimiliki oleh PT Timah (TINS) pada tahun 2015 dan yang tertinggi PT Adhi Karya (ADHI) pada tahun 2016.

Nilai minimum Size sebesar 9,64 dan maksimum sebesar 15,02. Sementara nilai standar deviasi Size sebesar 1,22593 dengan nilai rata rata Size yang dimiliki perusahaan BUMN periode 2013 -2016 adalah 13,4310. Nilai terendah dimiliki oleh PT Perusahaan Gas Negara (PGAS) pada tahun 2013 dan yang tertinggi PT Bank Mandiri (BMRI) pada tahun 2016.

Nilai minimum ROA (Return On Aset) sebesar 0,00 dan maksimum sebesar 0,59. Sementara nilai standar deviasi ROA sebesar 0,11290 dengan nilai rata rata ROA yang dimiliki perusahaan BUMN periode 2013 -2016 adalah 0,0995. Nilai terendah dimiliki oleh PT Jasa Marga (JSMR) pada tahun 2013 dan yang tertinggi PT Timah (TINS) pada tahun 2016.

Nilai minimum DER (Debt Equity Ratio) sebesar 0,37dan maksimum sebesar 11,40. Sementara nilai standar deviasi DER sebesar 2,97000 dengan nilai rata rata DER yang dimiliki perusahaan BUMN periode 2013 -2016 adalah 3,2118. Nilai terendah dimiliki oleh PT Semen Indonesia (SMGR) pada tahun 2014 dan yang tertinggi PT Bank Tabungan Negara (BBTN) pada tahun 2015.

Nilai minimum CIR (Capital Intensity Ratio) sebesar 0,01 dan maksimum sebesar 0,70. Sementara nilai standar deviasi CIR sebesar 0,21282 dengan nilai rata rata CIR yang dimiliki perusahaan BUMN periode 2013 -2016 adalah 0,1855. Nilai terendah dimiliki oleh PT Pembangunan Perumahan (PTPP) pada tahun 2013, PT Bank Negara Indonesia (BBNI) pada tahun 2013\&2014, PT Bank Rakyat Indonesia pada tahun 2013,2014 dan 2015, PT Bank Tabungan Negara (BBTN) pada tahun2013,2014 dan 2015, PT Bank Mandiri (BMRI)pada tahun2013,2014 dan 2015 dan yang tertinggi PT Semen Indonesia (SMGR) pada tahun 2016.

Nilai minimum OWNMANAG (Owner Managemen) sebesar 0,00 dan maksimum sebesar 0,04. Sementara nilai standar deviasi OWNMANAG sebesar 0,00530 dengan nilai rata rata OWNMANAG yang dimiliki perusahaan BUMN periode 2013 -2016 adalah 0,0008. Nilai terendah dimiliki semua perusahaan kecuali PT Bank Tabungan Negara (BBTN) pada tahun 2013 dan PT Pembangunan Perumahan (PTPP) pada tahun 2014 dan yang tertinggi PT Pembangunan Perumahan (PTPP) pada tahun 2014.

Nilai minimum OWNINST (Owner Institution) sebesar 0,06 dan maksimum sebesar 0,72. Sementara nilai standar deviasi OWNINST sebesar 0,13817 dengan nilai rata rata OWNINST yang dimiliki perusahaan BUMN periode 2013 -2016 adalah 0,3480. Nilai terendah dimiliki oleh PT Kimia Farma (KAEF) pada tahun 2013,2014,2015 dan yang tertinggi PT Bukit Asam (PTBA) pada tahun 2014.

Untuk memperjelas gambaran tiap - tiap variabel, berikut rata - rata variabel tiap periode:

\begin{tabular}{|l|l|l|l|l|l|l|l|}
\hline TAHUN & ETR & SIZE & ROA & DER & CIR & OWNMANAG & OWNINST \\
\hline 2013 & 0,214519067 & 9,976702 & 0,076493 & 2,608668 & 0,133854 & 0,001104159 & 0,250966835 \\
\hline 2014 & 0,214216146 & 10,03583 & 0,067909 & 2,610106 & 0,134267 & 0,002585144 & 0,274158764 \\
\hline 2015 & 0,172636829 & 10,10174 & 0,080556 & 2,301066 & 0,144024 & 0,000496264 & 0,27036105 \\
\hline 2016 & 0,166368321 & 10,17937 & 0,075031 & 2,114653 & 0,144017 & 0,000125409 & 0,249905392 \\
\hline
\end{tabular}

Tabel 2 Rata - rata Variabel Penelitian Periode 2013-2016

Dari tabel diatas, terlihat bahwa nilai ETR mengalami penurunan pada setiap tahunnya. Sedangkan yang mengalami kenaikan adalah Size dan CIR (Capital Intensity Ratio). Yang mengalami fluktuasi adalah variabel ROA, DER, OWNMANAG dan OWNINST. 


\section{Hasil Pengolahan Data}

Untuk mengestimasi parameter model dengan data panel, terdapat beberapa teknik yang digunakan (Nachrowi dan Usman 2006; Gujarati dan Porter, 2015), yaitu:

\section{Pooled Least Square (Common Effect)}

Hasil olah data Pooled Least Square (Common Effect) menggunakan E-views versi 9 sebagai berikut:

Tabel 3 Hasil olah data Pooled Least Square (Common Effect)

Dependent Variable: ETR

Method: Panel Least Squares

Date: 07/24/18 Time: 13:12

Sample: 20132016

Periods included: 4

Cross-sections included: 15

Total panel (balanced) observations: 60

\begin{tabular}{cclcc}
\hline \hline Variable & Coefficient & Std. Error & t-Statistic & Prob. \\
\hline \hline C & 0.386388 & 0.150276 & 2.571197 & 0.0130 \\
ROA & -0.399904 & 0.132106 & -3.027138 & 0.0038 \\
DER & -0.005718 & 0.006473 & -0.883470 & 0.3810 \\
SIZE & -0.004004 & 0.011845 & -0.338013 & 0.7367 \\
CIR & -0.038143 & 0.087159 & -0.437622 & 0.6634 \\
OWNMANAG & 3.883779 & 2.344475 & 1.656567 & 0.1035 \\
OWNINST & -0.041040 & 0.100970 & -0.406461 & 0.6860 \\
\hline \hline R-squared & 0.238323 & Mean dependent var & 0.256333 \\
Adjusted R-squared & 0.152095 & S.D. dependent var & 0.100776 \\
S.E. of regression & 0.092796 & Akaike info criterion & -1.807537 \\
Sum squared resid & 0.456392 & Schwarz criterion & -1.563197 \\
Log likelihood & 61.22612 & Hannan-Quinn criter. & -1.711962 \\
F-statistic & 2.763877 & Durbin-Watson stat & 1.031885 \\
Prob(F-statistic) & 0.020619 & & & \\
& & & & \\
\hline
\end{tabular}

Sumber : Eviews versi 9, 2018 


\section{Fixed Effect Model}

Hasil olah data Fixed Effect Modelmenggunakan E-views versi 9 sebagai berikut: Tabel 4 Hasil olah data Fixed Effect Model

Dependent Variable: ETR

Method: Panel Least Squares

Date: 07/24/18 Time: 13:18

Sample: 20132016

Periods included: 4

Cross-sections included: 15

Total panel (balanced) observations: 60

\begin{tabular}{ccccc}
\hline \hline Variable & Coefficient & Std. Error & t-Statistic & Prob. \\
\hline \hline C & 3.891793 & 0.942341 & 4.129922 & 0.0002 \\
ROA & -0.519528 & 0.110714 & -4.692521 & 0.0000 \\
DER & 0.022174 & 0.015094 & 1.469073 & 0.1498 \\
SIZE & -0.278020 & 0.068388 & -4.065349 & 0.0002 \\
CIR & 0.503975 & 0.278616 & 1.808853 & 0.0782 \\
OWNMANAG & 0.203365 & 1.704143 & 0.119336 & 0.9056 \\
OWNINST & -0.041834 & 0.081227 & -0.515027 & 0.6094 \\
\hline \hline
\end{tabular}

Effects Specification

Cross-section fixed (dummy variables)

\begin{tabular}{lcll}
\hline \hline R-squared & 0.785060 & Mean dependent var & 0.256333 \\
Adjusted R-squared & 0.674835 & S.D. dependent var & 0.100776 \\
S.E. of regression & 0.057466 & Akaike info criterion & -2.606037 \\
Sum squared resid & 0.128790 & Schwarz criterion & -1.873016 \\
Log likelihood & 99.18110 & Hannan-Quinn criter. & -2.319312 \\
F-statistic & 7.122315 & Durbin-Watson stat & 2.146457 \\
Prob(F-statistic) & 0.000000 & & \\
& & & \\
\hline
\end{tabular}

Sumber : Eviews versi 9, 2018 


\section{Random Effect Model}

Hasil olah data Random Effect Modelmenggunakan E-views versi 9 sebagai berikut:

Tabel 5 Hasil olah data Random Effect Model

Dependent Variable: ETR

Method: Panel EGLS (Cross-section random effects)

Date: 07/24/18 Time: 13:20

Sample: 20132016

Periods included: 4

Cross-sections included: 15

Total panel (balanced) observations: 60

Swamy and Arora estimator of component variances

\begin{tabular}{ccccc}
\hline \hline Variable & Coefficient & Std. Error & t-Statistic & Prob. \\
\hline \hline C & 0.724293 & 0.218753 & 3.311013 & 0.0017 \\
ROA & -0.429297 & 0.103148 & -4.161936 & 0.0001 \\
DER & 0.012757 & 0.007923 & 1.610158 & 0.1133 \\
SIZE & -0.034900 & 0.016668 & -2.093818 & 0.0411 \\
CIR & 0.101264 & 0.113225 & 0.894362 & 0.3752 \\
OWNMANAG & 1.208720 & 1.613019 & 0.749353 & 0.4570 \\
OWNINST & -0.049622 & 0.076264 & -0.650661 & 0.5181 \\
\hline \hline
\end{tabular}

Effects Specification

S.D. Rho

\begin{tabular}{llr}
\hline \hline Cross-section random & 0.066715 & 0.5741 \\
Idiosyncratic random & 0.057466 & 0.4259
\end{tabular}

Weighted Statistics

\begin{tabular}{lclc}
\hline \hline R-squared & 0.254901 & Mean dependent var & 0.101394 \\
Adjusted R-squared & 0.170550 & S.D. dependent var & 0.075243 \\
S.E. of regression & 0.068527 & Sum squared resid & 0.248888 \\
F-statistic & 3.021916 & Durbin-Watson stat & 1.415563
\end{tabular}


Prob(F-statistic) $\quad 0.012913$

\begin{tabular}{lllr}
\hline \hline & Unweighted Statistics & \\
\hline \hline R-squared & 0.069585 & Mean dependent var & 0.256333 \\
Sum squared resid & 0.557499 & Durbin-Watson stat & 0.631959 \\
& & & \\
\hline \hline
\end{tabular}

Sumber: Eviews versi 9, 2018

Setelah di dapat hasil pengolahan data menggunakan Eviews seperti 3 tabel diatas, selanjutnya akan dilakukan pemilihan model estimasi untuk mendapatkan pendekatan terbaik dalam analisis regresi data panel. Ada beberapa uji yang harus dilakukan antara lain:

1. Uji F Restricted (Chow Test)

Hasil Uji F Restricted (Chow Test)menggunakan E-views versi 9 sebagai berikut:

Tabel 6 Hasil Uji F Restricted (Chow Test)

Redundant Fixed Effects Tests

Equation: FE

Test cross-section fixed effects

\begin{tabular}{lrrr}
\hline \hline Effects Test & Statistic & d.f. & Prob. \\
\hline \hline Cross-section F & & & \\
Cross-section Chi-square & 7.085967 & $(14,39)$ & 0.0000 \\
& 75.909955 & 14 & 0.0000 \\
\hline \hline
\end{tabular}

Cross-section fixed effects test equation:

Dependent Variable: ETR

Method: Panel Least Squares

Date: $07 / 24 / 18$ Time: 13:24

Sample: 20132016

Periods included: 4

Cross-sections included: 15

Total panel (balanced) observations: 60

\begin{tabular}{ccccc}
\hline \hline Variable & Coefficient & Std. Error & t-Statistic & Prob. \\
\hline \hline $\mathrm{C}$ & 0.386388 & 0.150276 & 2.571197 & 0.0130
\end{tabular}


Jurnal AKUNTANSI, Vol. 7 No. 1 \#April \#2018

\begin{tabular}{ccccc} 
ROA & -0.399904 & 0.132106 & -3.027138 & 0.0038 \\
DER & -0.005718 & 0.006473 & -0.883470 & 0.3810 \\
SIZE & -0.004004 & 0.011845 & -0.338013 & 0.7367 \\
CIR & -0.038143 & 0.087159 & -0.437622 & 0.6634 \\
OWNMANAG & 3.883779 & 2.344475 & 1.656567 & 0.1035 \\
\multicolumn{1}{c}{ OWNINST } & -0.041040 & 0.100970 & -0.406461 & 0.6860 \\
& & & & \\
\hline \hline R-squared & 0.238323 & Mean dependent var & 0.256333 \\
Adjusted R-squared & 0.152095 & S.D. dependent var & 0.100776 \\
S.E. of regression & 0.092796 & Akaike info criterion & -1.807537 \\
Sum squared resid & 0.456392 & Schwarz criterion & -1.563197 \\
Log likelihood & 61.22612 & Hannan-Quinn criter. & -1.711962 \\
F-statistic & 2.763877 & Durbin-Watson stat & 1.031885 \\
Prob(F-statistic) & 0.020619 & & \\
\hline
\end{tabular}

Sumber : Eviews versi 9, 2018

Dari hasilUji F Restricted (Chow Test) cukup diperhatikan nilai probabilitas (Prob.) untuk Cross-section F. Jika nilai $>0,05$ (tingkat signifikan) maka model yang terpilih Common Effect (CE), tetapi jika $<0,05$ maka model yang terpilih Fixed Effect (FE). Pada tabel diatas terlihat bahwa nilai Prob. Cross-section F sebesar 0,0000 yang nilainya $<0,05$ sehingga dapat disimpulkan bahwa model FE lebih tepat dibandingkan dengan model CE.

2. Uji Hausman

Hasil Uji Hausmanmenggunakan E-views versi 9 sebagai berikut:

Tabel 7 Hasil Uji Hausman

Correlated Random Effects - Hausman Test

Equation: RE

Test cross-section random effects

\begin{tabular}{lccc}
\hline \hline Test Summary & Chi-Sq. Statistic & Chi-Sq. d.f. & Prob. \\
\hline \hline Cross-section random & 28.367580 & 6 & 0.0001 \\
\hline \hline
\end{tabular}

Cross-section random effects test comparisons: 


\begin{tabular}{ccccc} 
Variable & Fixed & Random & Var(Diff.) & Prob. \\
\hline \hline ROA & -0.519528 & -0.429297 & 0.001618 & 0.0249 \\
DER & 0.022174 & 0.012757 & 0.000165 & 0.4636 \\
SIZE & -0.278020 & -0.034900 & 0.004399 & 0.0002 \\
CIR & 0.503975 & 0.101264 & 0.064807 & 0.1137 \\
OWNMANAG & 0.203365 & 1.208720 & 0.302272 & 0.0675 \\
OWNINST & -0.041834 & -0.049622 & 0.000782 & 0.7806 \\
\hline \hline
\end{tabular}

Cross-section random effects test equation:

Dependent Variable: ETR

Method: Panel Least Squares

Date: 07/24/18 Time: 13:25

Sample: 20132016

Periods included: 4

Cross-sections included: 15

Total panel (balanced) observations: 60

\begin{tabular}{ccccc}
\hline \hline Variable & Coefficient & Std. Error & t-Statistic & Prob. \\
\hline \hline C & 3.891793 & 0.942341 & 4.129922 & 0.0002 \\
ROA & -0.519528 & 0.110714 & -4.692521 & 0.0000 \\
DER & 0.022174 & 0.015094 & 1.469073 & 0.1498 \\
SIZE & -0.278020 & 0.068388 & -4.065349 & 0.0002 \\
CIR & 0.503975 & 0.278616 & 1.808853 & 0.0782 \\
OWNMANAG & 0.203365 & 1.704143 & 0.119336 & 0.9056 \\
OWNINST & -0.041834 & 0.081227 & -0.515027 & 0.6094 \\
\hline \hline
\end{tabular}

Effects Specification

Cross-section fixed (dummy variables) 


\begin{tabular}{lccr} 
R-squared & 0.785060 & Mean dependent var & 0.256333 \\
Adjusted R squared & 0.674835 & S.D. dependent var & 0.100776 \\
S.E. of regression & 0.057466 & Akaike info criterion & -2.606037 \\
Sum squared resid & 0.128790 & Schwarz criterion & -1.873016 \\
Log likelihood & 99.18110 & Hannan-Quinn criter. & -2.319312 \\
F-statistic & 7.122315 & Durbin-Watson stat & 2.146457 \\
Prob(F-statistic) & 0.000000 & & \\
\hline
\end{tabular}

Sumber: Eviews versi 9, 2018

Dari hasil uji Hausman Test cukup diperhatikan nilai probabilitas (Prob.) untuk Cross-section random. Jika nilai > 0,05 (tingkat signifikan) maka model yang terpilih Random Effect (RE), tetapi jika < 0,05 maka model yang terpilih Fixed Effect (FE). Pada tabel diatas terlihat bahwa nilai Prob.Cross-section random sebesar 0,0001yang nilainya $<0,05$ sehingga dapat disimpulkan bahwa model FE lebih tepat dibandingkan dengan model RE. Karena hasil pada uji Hausman Testmemilih FE maka harus dilakukan uji heteroskedastisitas. Heteroskedastisitas biasanya terjadi pada jenis data cross section. Karena regresi data panel memiliki karakteristik tersebut, maka kemungkinan terjadi heteroskedastisitas. Model regresi data panel yang kemungkinan heteroskedastisitas adalah CE dan FE.

Hasil Uji Heteroskedastisitas menggunakan E-views versi 9 sebagai berikut:

\section{Tabel 8 Hasil Uji Heteroskedastisitas}

Dependent Variable: ETR

Method: Panel EGLS (Cross-section weights)

Date: 08/18/18 Time: 10:39

Sample: 20132016

Periods included: 4

Cross-sections included: 15

Total panel (balanced) observations: 60

Linear estimation after one-step weighting matrix

\begin{tabular}{ccccc}
\hline \hline Variable & Coefficient & Std. Error & t-Statistic & Prob. \\
\hline \hline C & 2.747246 & 0.474479 & 5.790029 & 0.0000 \\
ROA & -0.604385 & 0.072634 & -8.321010 & 0.0000 \\
DER & 0.021657 & 0.003820 & 5.668863 & 0.0000
\end{tabular}


Jurnal AKUNTANSI, Vol. 7 No. 1 \#April \#2018

\begin{tabular}{ccccc} 
SIZE & -0.190533 & 0.035648 & -5.344804 & 0.0000 \\
CIR & 0.377350 & 0.089570 & 4.212907 & 0.0001 \\
OWNMANAG & 0.334230 & 0.566998 & 0.589473 & 0.5589 \\
OWNINST & -0.033221 & 0.011711 & -2.836805 & 0.0072 \\
\hline \hline
\end{tabular}

Effects Specification

Cross-section fixed (dummy variables)

Weighted Statistics

\begin{tabular}{llll}
\hline \hline R-squared & 0.925282 & Mean dependent var & 0.595109 \\
Adjusted R-squared & 0.886965 & S.D. dependent var & 0.712684 \\
S.E. of regression & 0.049740 & Sum squared resid & 0.096487 \\
F-statistic & 24.14812 & Durbin-Watson stat & 1.929475 \\
Prob(F-statistic) & 0.000000 & &
\end{tabular}

Unweighted Statistics

\begin{tabular}{llll}
\hline \hline R-squared & 0.767885 & Mean dependent var & 0.256333 \\
Sum squared resid & 0.139082 & Durbin-Watson stat & 2.019921
\end{tabular}

Sumber: diolah oleh peneliti, 2018

Dari hasil uji heteroskedastisitas tersebut diatas kemudian dibandingkan dengan hasil model FE.

Tabel 9 Perbandingan Hasil FE Unweighted dan Weighted.

\begin{tabular}{|l|l|l|}
\hline Parameter & FE Unweighted & FE weighted \\
\hline Prob. t- Statistic & $\begin{array}{l}\text { 2variabel }<0,05 \\
\text { 4variabel }>0,05\end{array}$ & $\begin{array}{l}\text { 5variabel }<0,05 \\
\text { 1variabel }>0,05\end{array}$ \\
\hline R-squared & 0,785060 & 0,925282 \\
\hline Prob(F-statistic) & 0,00000 & 0,00000 \\
\hline
\end{tabular}

Sumber: diolah oleh peneliti, 2018

Dari tabel tersebut, berdasarkan 3 parameter diatas dapat kita lihat berbedaan Rsquarenya model FE weighted lebih besar (lebih baik) sehingga hasil yang akan di gunakan pada penelitian ini adalah hasil terakhir / FE weighted. 


\section{PEMBAHASAN}

Berdasarkan hasil pengujian yang telah dilakukan, ditemukan beberapa hasilpenelitian. Hasil tersebut menunjukkan bahwa ROA, SIZE, OWNINST berpengaruh negative signifikan terhadap penghindaran pajak.DER \& CIRberpengaruh positif signifikan. SedangkanOWNMANAG, berpengaruh positif tidak signifikan atau tidak berpengaruh terhadap penghindaran pajak.

\section{Pengaruh Karakteristik Perusahaan terhadap Penghindaran Pajak}

Dari hasil pengujian karakteristik perusahaan yang diproksikan pada ROA, DER, Size, CIR, dari variabel tersebut ROA, SIZE berpengaruh negative signifikan terhadap penghindaran pajak, sedangkan DER \& CIRberpengaruh positif signifikan.

\section{Pengaruh Struktur Kepemilikan terhadap Penghindaran Pajak}

Dari hasil pengujian struktur kepemilikan perusahaan yang di proksikan pada kepemilikan manajemen memiliki pengaruh positif tetapi tidak signifikan / tidak berpengaruh dan kepemilikan institusi berpengaruh negative signifikan.

Untuk kepemilikan manajerial, hasil penelitian ini menyatakan kepemilikan manajerial berpengaruh positif tidak signifikan terhadap penghindaran pajak atau tidak berpengaruh terhadap penghindaran pajak.

Hasil tersebut tidak konsisten dengan hasil penelitian yang dilakukan Atari (2016) yang menyatakan bahwa kepemilikan manajerial berpengaruh positif signifikan terhadap penghindaran pajak dan konsisten terhadap hasil penelitian Hadi (2014) dan Sari (2015) yang menyatakan kepemilikan manajerial didalam suatu perusahaan tidak berpengaruh terhadap penghindaran pajak.

\section{PENUTUP}

\section{Kesimpulan}

Berdasarkan analisa dan uji data yang telah dilakukan dalam penelitian ini, maka beberapa kesimpulan yang dapat diambil adalah sebagai berikut:

Pengaruh kareakteristik perusahaan yang di proksikan pada Profitabilitas (ROA), Leverage (DER), Size, dan CIR. Variabel Profitabilitas (ROA) dan Size berpengaruh negative signifikan terhadap penghindaran pajak. DER dan CIR berpengaruh positif signifikan terhadap penghindaran pajak.

Pengaruh Struktur Kepemilikan yang diproksikan pada kepemilikan manajerial berpengaruh positif tidak signifikan terhadap penghindaran pajak dan kepemilikan institusional berpengaruh negative signifikan terhadap penghindaran pajak.

Saran

Adapun saran yang dapat peneliti ajukan untuk peneliti - peneliti selanjutnya di bidang perpajakn, terutama untuk melihat tingkat penghindaran pajak di suatu perusahaan adalah:

Untuk peneliti selanjutnya disarankan untuk menambah variabel dependen lain yang erat kaitannya dengan penghindaran pajak. Contohnya political conection, undang undang pajak yang di berlakukan / reformasi pajak dan masih banyak lagi.

Peneliti selanjutnya di harapkan menambah rentan waktu dan jumlah perusahaan yang lebih banyak. Agar penelitian penghindaran pajak dapat tercover secara keseluruhan.

\section{DAFTAR RUJUKAN}

Ardyansah, Danis. (2014). Pengaruh Size, Leverage, Profitabilitas, Capital Intensity Ratio dan Komisaris Independen Terhadap Effective Tax Rate (ETR). Skripsi Universitas Diponegoro Semarang

Astuti, Titiek Pujidan Y. Anni Aryani. (2016). Tren Penghindaran Pajak Perusahaan Manufaktur Di Indonesia Yang Terdaftar Di BeiTahun 2001-2014. Jurnal Akuntansi/Volume XX, No. 03, September 2016: 375-388 
Arfan, M. Gardo. (2016). Pengaruh Karakteristik Perusahaan dan kepemilikan Keluarga terhadap Penghindaran Pajak. Skripsi Universitas Bandar Lampung

Atari, Jeane. (2016). Pengaruh Kepemilikan Manajerial, Kepemilikan Institusional, dan Kebijakan Hutang Terhadap Tax Aggressive: Studi Empiris Pada Perusahaan Transportasi Yang Terdaftar Di Bursa Efek Indonesia Periode 2011-2013. JOM Fekon, Vol.3 No.1

Hijriani, Anisa Nadia et.al. (2014). Pengaruh Koneksi Politik, Dewan Komisaris dan Karakteristik Perusahaan terhadap Penghindaran Pajak (Perusahaan BUMN yang terdaftar di BEI). Jurnal Reviu Akuntansi dan Keuangan ISSN: 2088-0685 Vol.4, No.1, Pp 525-534.

Kasmir. (2016). Analisis Laporan Keuangan. Jakarta: PT Raja Grafindo Persada

Kuriah, Hanik Lailatul. (2016). Pengaruh Karakteristik Perusahaan danCorporate Social Responsibility terhadap Agresivitas Pajak: Jurnal Ilmu dan Riset Akuntansi: Vol.5, No.3, ISSN 2460- 0585

Mahadewi, Istri Sri \& Komang Ayu Krisna dewi. (2017). Pengaruh Kepemilikan Manajerial, Institusional dan Proporsi Dewan Komisaris Independen pada Manajemen Laba. EJurnal akuntansi Universitas Udayana Vol.18, No.1, Hal.443-470, ISSN: 2302-8556.

Mardiasmo, 2011. Perpajakan. Edisi Revisi. Penerbit ANDI. Yogyakarta

Rochmat, Soemitro, 1992. "Pengantar Singkat Hukum Pajak", Bandung: PT. Eresco

Rosalia, Yuliesti \& Sapari. (2017). Pengaruh Profitabilitas, Likuiditas, dan Corporate Governance terhadap Penghindaran Pajak. Jurnal Ilmu dan Riset Akuntansi Vol.6, No.3 ISSN: 2460-0585.

Siregar, Rifka\&Dini Widyawati. (2016). Pengaruh Karakteristik Perusahaan terhadap Penghindaran Pajakpada Perusahaan Manufaktur di BEI. Jurnal Ilmu dan Riset Akuntansi: Vol.5, No.2ISSN 2460- 0585.

Suandy, Erly. (2014). Perencanaan Pajak. Jakarta: Salemba Empat

Surbakti, Theresa Adelina. (2012). Pengaruh Karakteristik Perusahaan dan Reformasi Perpajakan Terhadap Penghindaran Pajak di Perusahaan Manufaktur. Skripsi UI

Utami, Nurindah Wahyu. (2013). Pengaruh Struktur Corporate Governance, Size Profitabilitas Perusahaan terhadap Tax Avoidance.Skripsi UNS

Wicaksono, Agung Prasetyo Nugroho. (2017). Koneksi Politik dan Agresivitas Pajak: Fenomena Di Indonesia. Jurnal Ilmu Akuntansivol 10 (1) P-ISSN: 1979-858X; E-ISSN: 2461-1190

Republik Indonesia. 2007. Undang-Undang Republik Indonesia No 28 tahun 2007, dan No 16 Tahun 2009 Ketentuan Umum dan Tata Cara Perpajakan.Diretorat Jendral Pajak. Sekretariat Negara: Jakarta. 